\title{
FSW WELDING OF Al-Mg ALLOY PLATES WITH INCREASED EDGE ROUGHNESS USING SQUARE PIN TOOLS OF VARIOUS SHOULDER GEOMETRIES
}

\author{
FSW VARJENJE PLOŠČ IZ Al-Mg ZLITINE S POVEČANO \\ HRAPAVOSTJO ROBOV Z ORODJEM S KVADRATNO KONICO IN \\ RAZLIČNO GEOMETRIJO BOKOV
}

\author{
Sebastian Balos, Leposava Sidjanin, Miroslav Dramicanin, Danka Labus Zlatanovic, \\ Aco Antic \\ Faculty of Technical Sciences, Department of Production Engineering, Trg Dositeja Obradovica 6, 21000 Novi Sad, Serbia \\ danlabus@uns.ac.rs
}

Prejem rokopisa - received: 2015-04-30; sprejem za objavo - accepted for publication: 2015-06-17

doi:10.17222/mit.2015.088

\begin{abstract}
In the paper, the influence of tool shoulder geometries on the mechanical properties and weld surface roughness of an Al-Mg alloy was studied. Different types of tools were used: with straight and concave profiles. Three concave-shoulder types were applied, with volume ratios of 0.5 and 0.9 of the square pin to the shoulder reservoir and one with three concentric semi-toroidal reservoirs with a volume ratio of 0.5 of the pin to the shoulder reservoir. The tensile and bend properties, hardness profiles and macro-features of welds were examined. It was found that the optimum tensile and bending properties were obtained when applying the tool with concentric reservoirs and the lowest welding speed. In this way, the widest nugget zone at the plate axis is obtained, as well as the thickest nugget-zone layer under the specimen surface, covering the thermomechanical and heat-affected zones. The overlapping of the nugget zone with the thermomechanical and heat-affected zones enables higher proof and ultimate tensile strengths compared to the base material. The surface-roughness parameters of the weld face are lower for the specimens welded with the tools with reservoirs and considerably lower than the base-material edge-surface roughness. Keywords: friction-stir welding, 5052 aluminum alloy, FSW parameters, joint properties, surface roughness
\end{abstract}

V članku je prikazana raziskava vpliva geometrije boka orodja na mehanske lastnosti in hrapavost površine zvara Al-Mg zlitine. Uporabljeni sta bili orodji $\mathrm{z}$ ravnim in konkavnim profilom. Uporabljene so bile tri vrste konkavnih bokov, z razmerjem volumna 0,5 in 0,9 bočnega rezervoarja ter kvadratne konice in eden s tremi poltoroidnimi koncentričnimi rezervoarji, $\mathrm{z}$ razmerjem volumnov 0,5 konica-bok. Preiskovane so bile natezne in upogibne lastnosti, profili trdote in makro izgled zvarov. Ugotovljeno je, da so bile optimalne natezne in upogibne lastnosti dobljene pri uporabi orodja s koncentričnimi rezervoarji pri najmanjši hitrosti varjenja. Na ta način se doseže najširše področje mešanja pod površino vzorca, ki pokriva termomehansko in toplotno vplivano področje. Prekrivanje področja mešanja s termomehanskim in toplotno vplivanim področjem, omogoča višjo mejo plastičnosti in višjo natezno trdnost, v primerjavi z osnovnim materialom. Parametri površinske hrapavosti čela zvara so manjši pri vzorcih zvarjenih z orodji z rezervoarji in so občutno nižji, kot je osnovna hrapavost roba materiala.

Ključne besede: torno vrtilno varjenje, aluminijeva zlitina 5052, parametri FSW, lastnosti spoja, hrapavost površine

\section{INTRODUCTION}

Friction-stir welding (FSW) is a solid-state metaljoining process that uses a specialized non-consumable rotating tool to join work pieces. ${ }^{1}$ It has been shown that FSW is a suitable welding method for joining the materials difficult to join using conventional welding techniques. The most notable are aluminium-zinc-magnesium and aluminium-copper heat-treated allyos. ${ }^{2-7}$ Furthermore, $\mathrm{Mg}$-alloys and dissimilar materials have been successfully welded by FSW. ${ }^{8-13}$ The main advantages of FSW are related to the fact that no melting occurs and, therefore, gas porosity is avoided. Also, no distortion occurs and no shielding gases or welding consumable materials are needed, leading to a relatively low energy input. ${ }^{14} \mathrm{~A}$ decisive influence on the weld performance comes from the welding tool and the parameters such as welding and rotational speeds, as well as the tilt angle, etc. On the other hand, the FSW tool geometry can be related to the pin and shoulder geometry and the relation between the pin and shoulder size.

The tool has three primary functions: heating, material movement and containment of the heated material between the tool shoulder and the base plate. ${ }^{15-16}$ The tool pin influences deformational and frictional heating, as well as shearing the material in front of and moving the material behind the tool. ${ }^{17-20}$ The geometry of the FSW tool pin can vary considerably: round and flat-bottom cylindrical or threaded pins were found to be adequate for aluminium-alloy plates of up to $12 \mathrm{~mm} .{ }^{17}$ Truncated cone pins were developed to weld plates thicker than $12 \mathrm{~mm}$ at higher welding speeds, while fluted pins add deformation to the weld line, increasing the possible welding speeds even further. ${ }^{15}$ Polygonal pins offer 12-25\% reduced traversing and forging forces at a comparable strength as fluted pins. ${ }^{21}$ However, thin metallic plates were reported to be welded with pinless tools as well. ${ }^{22}$ 
The shoulder of FSW tools influences a number of weld features: from the most basic ones such as the weld appearance and roughness, to microstructural characteristics influencing the weld strength. ${ }^{23-25}$ These features are obtained through the forging action aimed at a proper containment and consolidation of the base material. ${ }^{25} \mathrm{~A}$ number of shoulder designs emerged. The most basic shoulder type is straight in the profile, without any curvature. However, now the most common type is the concave shoulder of a certain volume (reservoir), usually requiring tilting of the tool by $2-4^{\circ}$.

Both mentioned types of shoulder enable a relatively simple fabrication and cleaning after the welding process. ${ }^{14-15,19}$ An alternative is a shoulder with features such as scrolls, ridges or concentric circles, generally aimed at increasing the welding speed, the deformation and the frictional heating. ${ }^{15,26-28}$ Convex shoulder tools with scrolls are characterized with an improved ability to weld curvatures, base material with mismatch tolerances and different-thickness workpieces. ${ }^{15}$ Finally, the friction-stir spot welding (FSSW) of polymers can be used with a one-piece tool or a tool with a pin and a sleeve to allow dissimilar polymers to be mixed in lap joints. ${ }^{29-30}$

Another variable is the tool material, which is tailored to the material to be welded. Aluminium and magnesium alloys can be welded using tool steels, most typically hot-work tool steel such as H13. However, copper and copper alloys demand the use of nickel- or tungsten-alloy tools, while steel welding is most often done with polycrystalline cubic boron-nitride (PCBN) or tungsten-carbide (WC) material. ${ }^{15}$

The aim of this paper is to study the influence of different shoulder geometries on mechanical and weld-surface properties. Namely, regardless of what type of shoulder geometry is applied, a careful optimization of welding parameters is needed to obtain adequate mechanical properties as well as an acceptable weld-face surface roughness, since rough weld tracks most often require rework. ${ }^{23}$ Therefore, the machining of quality weld tracks is desirable and can be achieved with an efficient FSW tool that combines this outcome with high mechanical properties, without the need for a tool tilt, improving the tool life and used on a relatively rough edge-surface textures of plates.

\section{EXPERIMENTAL WORK}

In this paper, the base material consisted of $\mathrm{Al}-\mathrm{Mg}$ EN-AW5052-0 plates of $5 \mathrm{~mm}$. The chemical composition of the aluminium alloy determined with an optical emission spectrometer ARL 3580 is given in Table 1. The mechanical properties of the workpiece material, tested with a WPM ZDM 5/91 tensile-testing machine, on the basis of three specimens, are given in Table 2.

The plates were machined to dimensions of $300 \mathrm{~mm}$ $\times 65 \mathrm{~mm}$, with the average roughness of the edge to be welded of $R_{\mathrm{a}}=7.67 \mu \mathrm{m}$ and the maximum peak rough- ness $\left(R_{\mathrm{Z}}\right)$ of $29.8 \mu \mathrm{m}$, corresponding to the sawing process. ${ }^{31}$ The samples were tightly placed into a steel fixture into a 130-mm-wide groove and secured by clamps. The fixture was fitted onto an adapted Prvomajska UHG universal milling machine with a power of $5.2 \mathrm{~kW}$. The tool used was made of X38CrMoV5-1 (H11) hot-work tool steel, having had its chemical composition tested with an ARL 2460 optical emission spectrometer, as given in Table 3. The hardness of all the FSW tools was $53 \mathrm{HRC}$, as measured with a WPM HPO-250 device. Four different tool geometries were used, all with four-sided pins of equal dimensions, Figure 1. It can be seen that three basic geometries were used: a straight profile without a reservoir (0-type), two concave shoulders with shoulder-to-pin ratios of 0.5 and 0.9 (5- and 9-type) and a feature shoulder with three concentric circles and the overall volume-to-pin ratio of 0.5 (53-type tool). FSW was done without a tool tilt, with a rotational speed of $925 \mathrm{~min}^{-1}$ and three welding speeds,

Table 1: Chemical composition of EN-AW 5052 aluminium alloy (in mass fractions, $w / \%)$

Tabela 1: Kemijska sestava aluminijeve zlitine EN-AW 5052 (v masnih odstotkih, $w / \%)$

\begin{tabular}{|c|c|c|c|c|c|c|c|}
\hline $\mathrm{Cu}$ & $\mathrm{Mn}$ & $\mathrm{Mg}$ & $\mathrm{Si}$ & $\mathrm{Fe}$ & $\mathrm{Zn}$ & $\mathrm{Ti}$ & $\mathrm{Al}$ \\
\hline 0.09 & 0.09 & 2.78 & 0.24 & 0.38 & 0.046 & 0.015 & balance \\
\hline
\end{tabular}

Table 2: Mechanical properties of EN-AW 5052-0

Tabela 2: Mehanske lastnosti EN-AW 5052-0

\begin{tabular}{|c|c|c|c|}
\hline $\begin{array}{c}\text { Proof strength } \\
R_{\mathrm{pBM}}(\mathrm{MPa})\end{array}$ & $\begin{array}{c}\text { Ultimate ten- } \\
\text { sile strength } \\
R_{\mathrm{mBM}}(\mathrm{MPa})\end{array}$ & $\begin{array}{c}\text { Elongation } \\
A_{\mathrm{BM}}(\%)\end{array}$ & $\begin{array}{c}\text { Vickers hard- } \\
\text { ness number } \\
\text { HV5 }\end{array}$ \\
\hline $124 \pm 10$ & $193 \pm 3$ & $22 \pm 1$ & $60 \pm 1$ \\
\hline
\end{tabular}

Table 3: Chemical composition of X38CrMoV5-1 tool steel (in mass fractions, $w / \%$ )

Tabela 3: Kemijska sestava orodnega jekla X38CrMoV5-1 (v masnih odstotkih, $w / \%$ )

\begin{tabular}{|c|c|c|c|c|c|c|c|c|}
\hline $\mathrm{C}$ & $\mathrm{Si}$ & $\mathrm{Mn}$ & $\mathrm{P}$ & $\mathrm{S}$ & $\mathrm{Cr}$ & $\mathrm{Mo}$ & $\mathrm{V}$ & $\mathrm{Fe}$ \\
\hline 0.37 & 1.01 & 0.38 & 0.017 & 0.0005 & 4.85 & 1.23 & 0.32 & balance \\
\hline
\end{tabular}

Table 4: Specimen-group designation system

Tabela 4: Sistem označevanja vzorcev

\begin{tabular}{|c|c|c|c|c|c|}
\hline $\begin{array}{l}\text { Shoulder } \\
\text { cavity/pin } \\
\text { volume } \\
\text { ratio }\end{array}$ & $\begin{array}{c}\text { Number of } \\
\text { shoulder } \\
\text { cavities }\end{array}$ & \begin{tabular}{|c|} 
Area of the \\
shoulder surface \\
parallel to the \\
base metal $\left(\mathrm{mm}^{2}\right)$
\end{tabular} & $\begin{array}{c}\text { Tool } \\
\text { designation }\end{array}$ & \begin{tabular}{|c|}
$\begin{array}{c}\text { Welding } \\
\text { speed } \\
(\mathrm{mm} / \mathrm{min})\end{array}$ \\
\end{tabular} & $\begin{array}{l}\text { Specimen } \\
\text { group } \\
\text { designation }\end{array}$ \\
\hline 0 & 0 & \multirow{3}{*}{374} & \multirow{3}{*}{0} & 17 & 01 \\
\hline 0 & 0 & & & 46 & 04 \\
\hline 0 & 0 & & & 91 & 09 \\
\hline 0.5 & 1 & \multirow{3}{*}{163} & \multirow{3}{*}{5} & 17 & 51 \\
\hline 0.5 & 1 & & & 46 & 54 \\
\hline 0.5 & 1 & & & 91 & 59 \\
\hline 0.5 & 3 & \multirow{3}{*}{226} & \multirow{3}{*}{53} & 17 & 531 \\
\hline 0.5 & 3 & & & 46 & 534 \\
\hline 0.5 & 3 & & & 91 & 539 \\
\hline 0.9 & 1 & \multirow{3}{*}{163} & \multirow{3}{*}{9} & 17 & 91 \\
\hline 0.9 & 1 & & & 46 & 93 \\
\hline 0.9 & 1 & & & 91 & 99 \\
\hline
\end{tabular}


a)

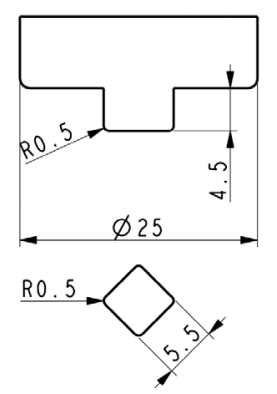

c)

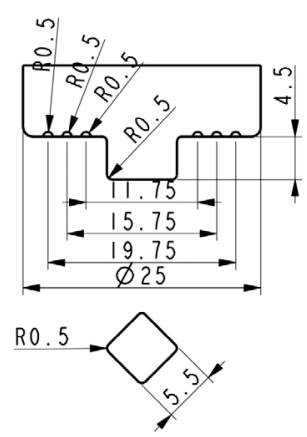

b)
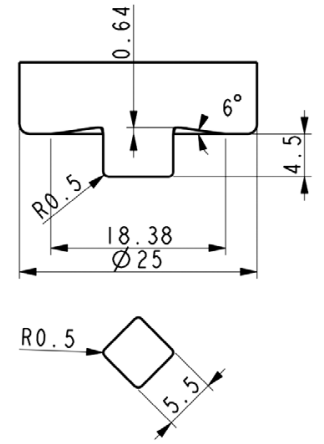

d)

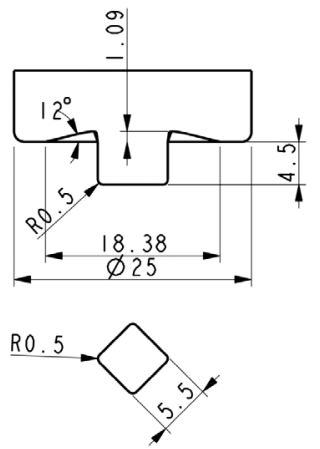

Figure 1: FSW tools: a) straight profile without a reservoir (0-type), b) concave shoulder with the shoulder-to-pin volume ratio of 0.5 (5-type), c) feature shoulder with three concentric circles with the overall-volume-to-pin ratio of 0.5 (53-type) and d) concave shoulder with the shoulder-to-pin volume ratio of 0.5 (9-type) 0.9

Slika 1: FSW orodja: a) raven profil brez hranilnika (0-vrsta), b) konkaven bok z razmerjem volumna na boku in konici 0,5 (5-vrsta), c) oblikovan bok s tremi koncentričnimi krogi z razmerjem skupni volumen-konica 0,5 (53-vrsta) in d) konkavni bok z razmerjem volumnov bok-konica 0,5 (9-vrsta) 0,9

Table 5: Tensile properties and standard deviations, joint efficiencies, fracture locations and angles of bend to the first crack Tabela 5: Natezne lastnosti in standardni odkloni, učinkovitost spojev, položaj porušitev in koti pri upogibanju do prve razpoke

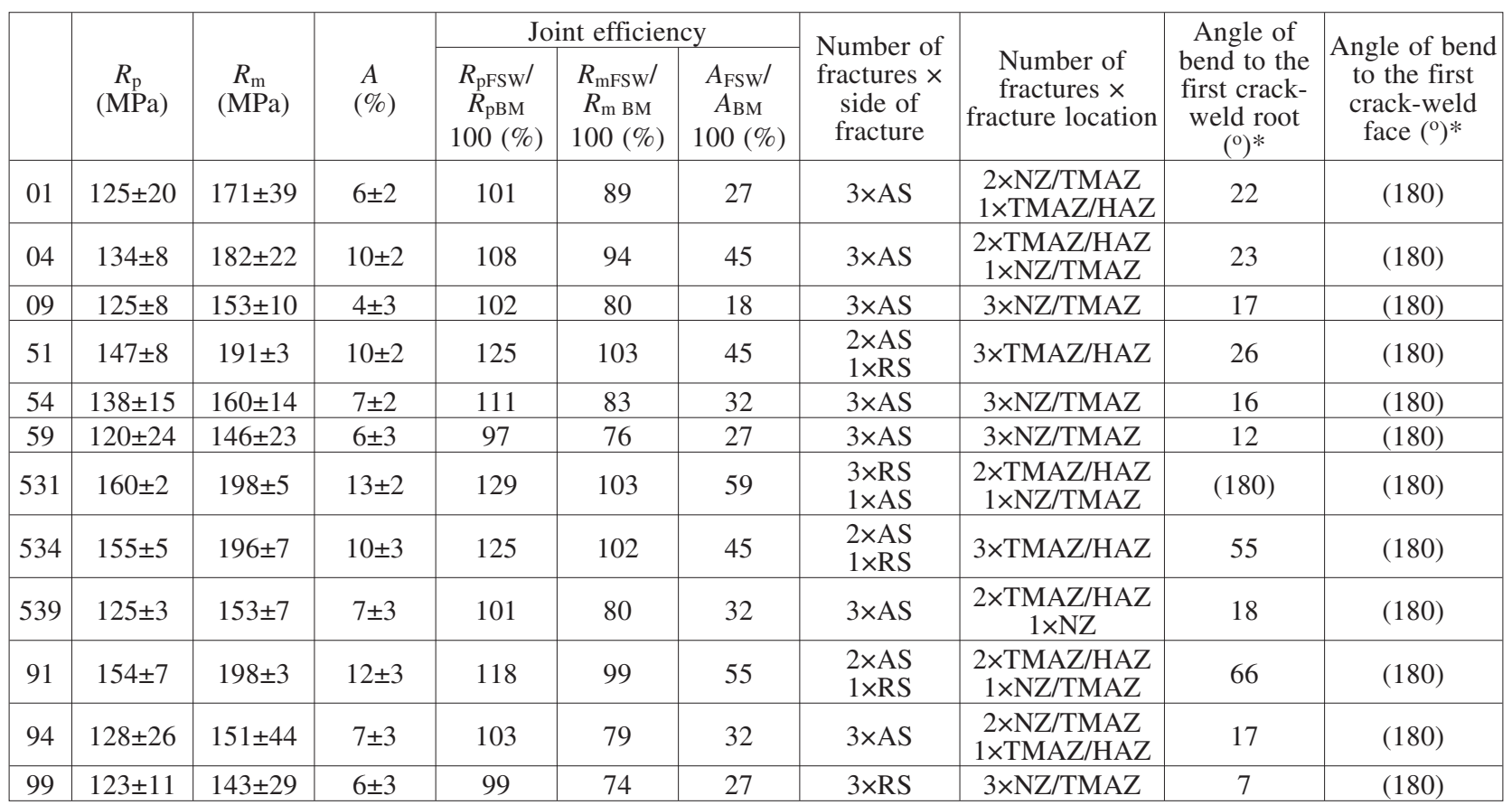

*Numbers in parentheses indicate that the cracking did not occur until the test was completed (until $180^{\circ}$ )

*Števila v oklepajih kažejo, da ni prišlo do razpok, dokler ni bil test zaključen (pri $180^{\circ}$ ) 

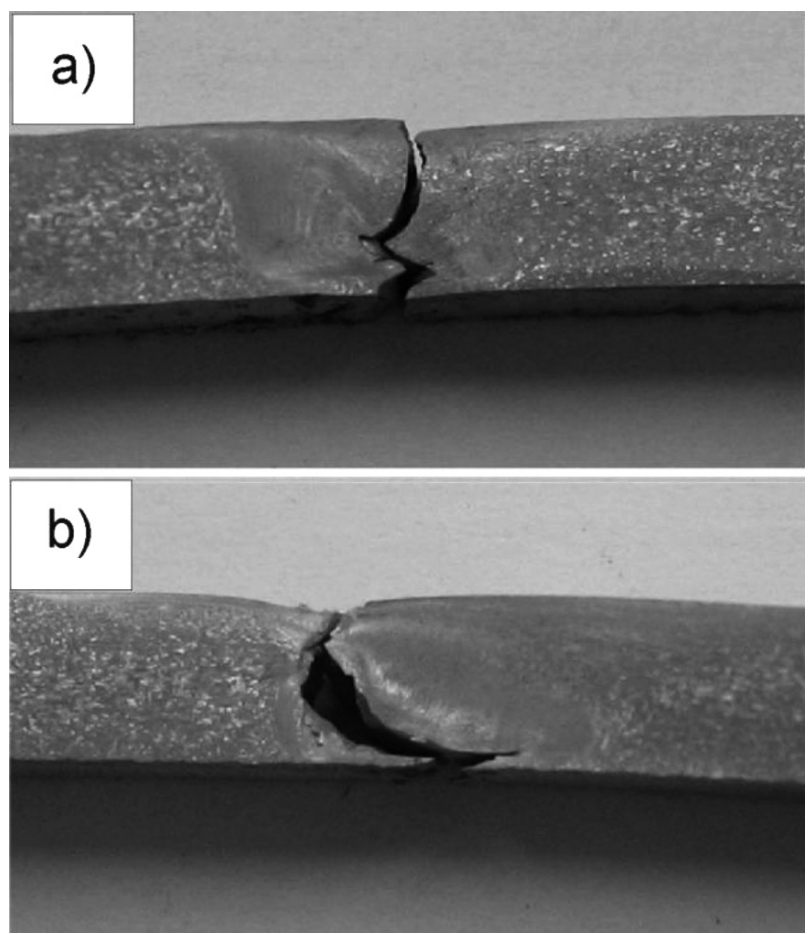

Figure 2: Fracture locations for tensile specimens: a) NZ on RS (specimen 539), b) NZ/TMAZ on AS (specimen 54)

Slika 2: Položaja preloma pri nateznem preizkušancu: a) NZ na RS (vzorec 539), b) NZ/TMAZ na AS (vzorec 54)

geometry clearly influences the tensile properties. The lowest values were obtained with the 0-type tool, followed by the 9-type tool, the 5-type tool and, finally, the highest mechanical properties were obtained with the 5- and 53-type tools. Furthermore, a clear correlation exists between the welding speed and the tensile properties for the 5-, 53- and 9-type tools. At lower welding speeds, the proof and tensile strengths, as well as the elongation increase. In the case of the 0-type tool, the highest tensile properties were achieved with a welding speed of $46 \mathrm{~mm} / \mathrm{min}$. The same trend can be observed for joint efficiencies, which are related to the basematerial tensile properties. Thus, the highest joint efficiencies were obtained with the 531 specimen group
(129\% proof-strength efficiency, $103 \%$ ultimate-tensile-strength efficiency and $59 \%$ elongation efficiency), followed by the 534 and 91 specimen groups. The lowest efficiencies were achieved with the 01, 09 and 99 specimen groups.

No clear influence of the welding speed on the tensile-property standard deviation can be observed. However, comparing the specimen groups obtained with different tools, a clear trend can be seen: the highest standard deviations were achieved with the straight profile shoulder (the 0-type tool; 01, 04, 09 specimen groups), while the lowest deviation was obtained with the three-circular-groove tool (the 53-type tool; 531, 534, 539 specimen groups). For the 0-type tool, the general trend shows a reduction in the standard deviations with an increase in the welding speed. An opposite trend can be observed with the 5-type tool. In the cases of the 53and 9-type tools, no clear correlation between the standard deviation and the welding speed can be made. Furthermore, no clear correlation between the tool shoulder design, the welding speed or the tensile/bend properties, and the side of fracture or the fracture location can be observed.

The fracture location for all the specimen groups is either in NZ/TMAZ (nugget zone/thermomechanical zone) or TMAZ/HAZ (thermomechanical zone/heat affected zone), with only one NZ fracture. The more frequent side of fracture was the advancing side (AS), in contrast to the retreating side (RS). Some cases of the fracture during the tension test are shown in Figure 2.

Angles of bend to the first crack can be positively correlated to tensile properties. Namely, as the tensile properties are higher, the angle of the first crack in the weld root is also higher. In the case of 531, the specimen was bent to $180{ }^{\circ}$ without cracking in the weld root. No cracking occurred in either specimen weld face. Some cases of bend testing are shown in Figure 3 .

Hardness profiles are shown in Figure 4. All the hardness profiles have a similar general shape, with the maximum attained hardness values at the middle of the chart, that is, in the NZ. However, some clear trends can be observed for all the specimen groups welded with the

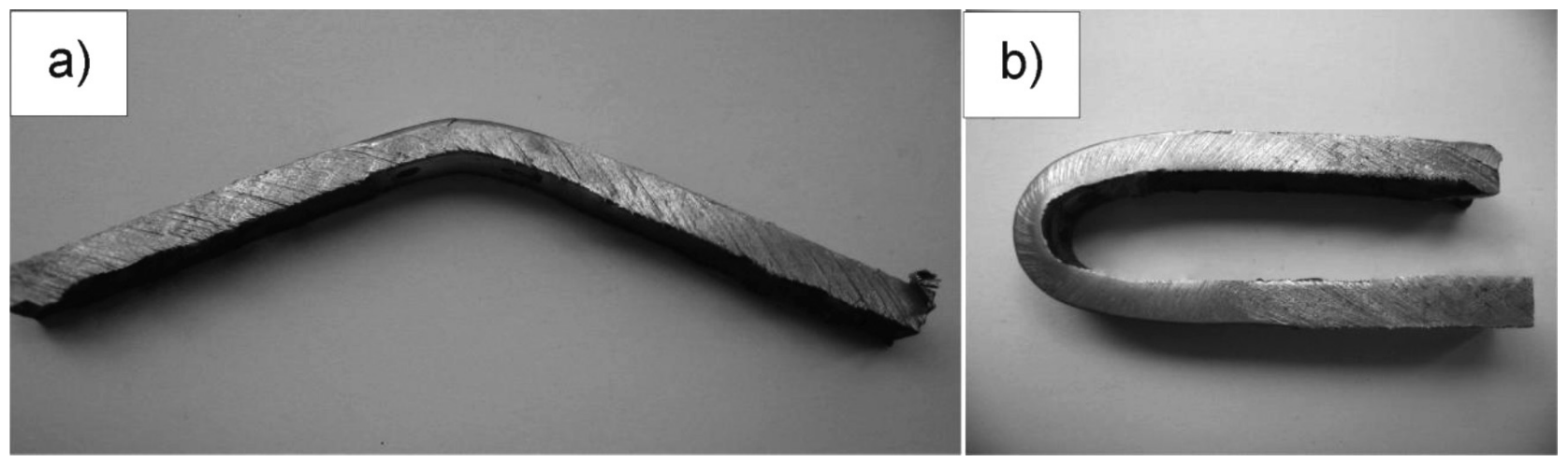

Figure 3: Bending to the first crack: a) specimen 04, b) specimen 531

Slika 3: Upogibanje do prve razpoke: a) vzorec 04, b) vzorec 531 

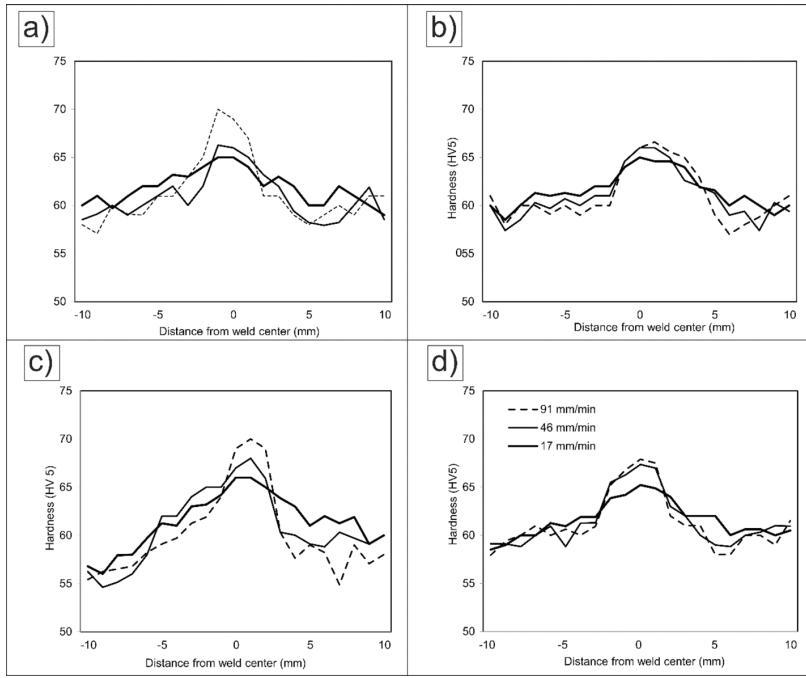

Figure 4: Hardness profiles of specimens welded with a tool rotational speed of $925 \min ^{-1}$ : a) 0-type tool, b) 5-type tool, c) 53-type tool, d) 9-type tool (welding speeds are indicated by different lines, shown in Figure 4d)

Slika 4: Profili trdote vzorcev zvarjenih s hitrostjo vrtenja $925 \mathrm{~min}^{-1}$ : a) 0 - vrsta orodja, b) 5 - vrsta orodja, c) 53 - vrsta orodja, d) $9-$ vrsta orodja (hitrosti varjenja so prikazane z različnimi linijami, obrazloženimi na Sliki 4d)

same FSW tool. Firstly, the hardness in the NZ is higher for the specimens welded at higher welding speeds. Secondly, an increase in the welding speed causes a drop in the hardness values for the TMAZ and HAZ zones (approximately 3-10 $\mathrm{mm}$ on either side of the NZ).

\subsection{Metallographic examinations}

The results of the metallographic examinations of the representative specimens obtained with the 5- and
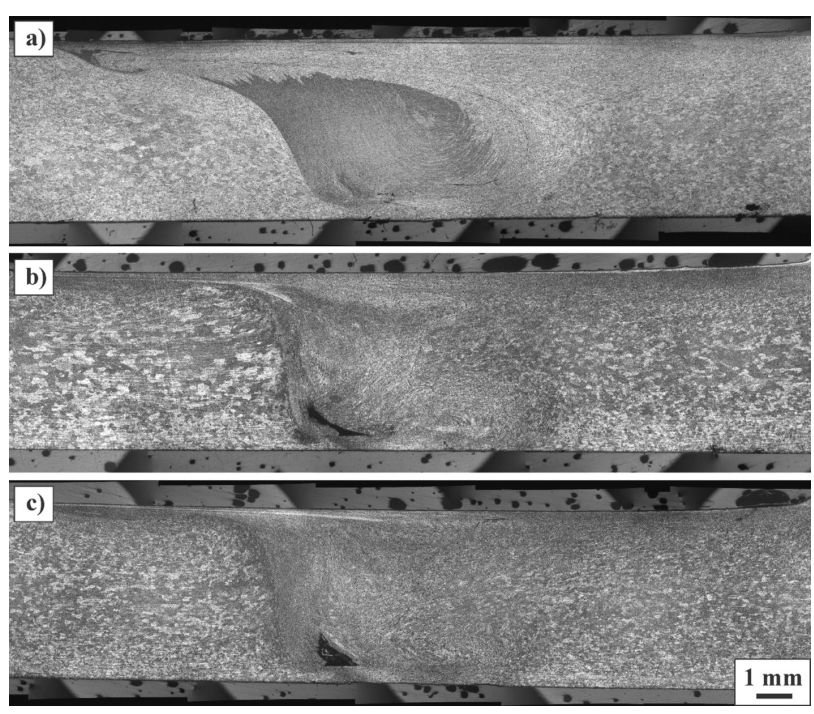

Figure 5: Macrographs of specimens welded with 5-type tool (rotational speed of $925 \mathrm{~min}^{-1}$ ): a) specimen 51 (welding speed of 17 $\mathrm{mm} / \mathrm{min})$, b) specimen 54 (46 mm/min), c) specimen $59(91 \mathrm{~mm} / \mathrm{min})$ Slika 5: Makroposnetki vzorcev zvarjenih z orodjem vrste 5 (hitrost vrtenja $925 \mathrm{~min}^{-1}$ ): a) vzorec 51 (hitrost varjenja $17 \mathrm{~mm} / \mathrm{min}$ ), b) vzorec $54(46 \mathrm{~mm} / \mathrm{min})$, c) vzorec $59(91 \mathrm{~mm} / \mathrm{min})$
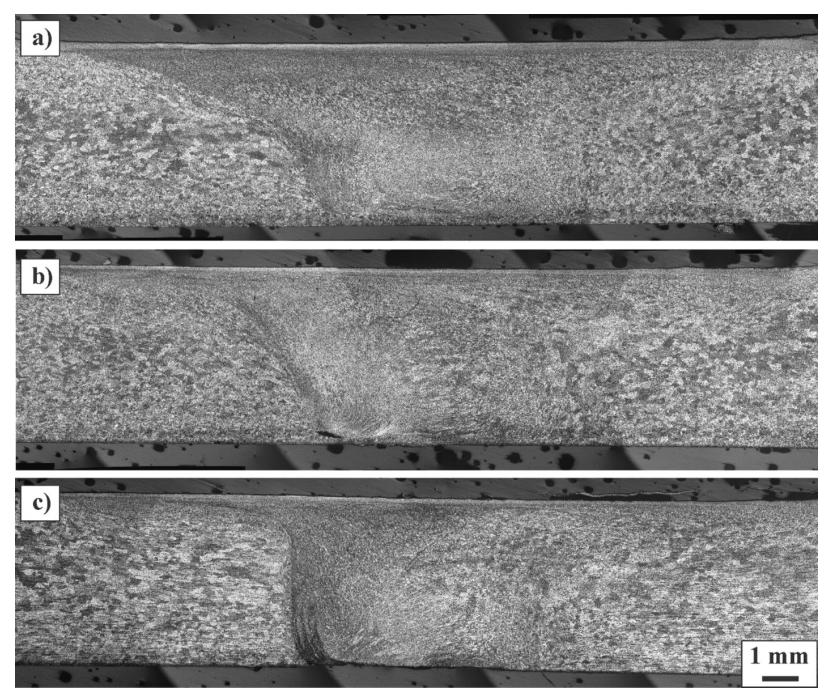

Figure 6: Macrographs of specimens welded with 53-type tool (rotational speed of $\left.925 \mathrm{~min}^{-1}\right)$ : a) specimen $531(17 \mathrm{~mm} / \mathrm{min}$ welding speed), b) specimen 534 (46 mm/min), c) specimen 539 (91 mm/min) Slika 6: Makroposnetki vzorcev zvarjenih z orodjem vrste 53 (hitrost vrtenja $925 \mathrm{~min}^{-1}$ ): a) vzorec 531 (hitrost varjenja $17 \mathrm{~mm} / \mathrm{min}$ ), b) vzorec 534 (46 mm/min), c) vzorec 539 (91 mm/min)

53-type tools are shown in Figures 5 and 6. It can be seen that multiple relatively small, tunnel-like defects occur in Specimen 51, Figure 5a. However, in Specimens 54 and 59, single larger tunnel-like defects appear at the bottom section of the NZ, on the advancing side. Also, by increasing the welding speed, a more pronounced tunnelling occurs. A similar trend of the increasing defect size can be seen in Figure 6, relating to the specimens welded with the 53-type tool. In Specimen 531, welded at the lowest welding speed, no tunnel-like defect occurs, while in Specimens 534 and 53, small-sized closed and open tunnels (root defects) occur.

The variation in the welding speed causes a change in the transition line between NZ and TMAZ on the advancing and retreating sides. This becomes closer to a vertical (normal to the specimen surface) as the welding speed increases. This means that the thickness of the refined zone under the specimen surface is higher in the specimens treated at a lower welding speed.

The macrostructures of the HAZ and TMAZ zones also vary depending on the type of tool used, as well as the welding speed. In Figure 5, for the 5-type tool, the lowest and the highest welding speeds of 17 and 91 $\mathrm{mm} / \mathrm{min}$ result in a finer microstructure. The same can be observed for Specimen 534, welded with the 53-type tool at the medium welding speed, Figure 6.

\subsection{Roughness of the weld face}

Roughness parameters of the FSW weld faces are given in Table 6. It can be seen that the obtained results are generally lower than those for the edges of the base material $\left(R_{\mathrm{a}}=7.67 \mu \mathrm{m} ; R_{\mathrm{z}}=29.8 \mu \mathrm{m}\right)$. The highest surface roughness is obtained with the 0-type tool 
without a reservoir in the shoulder, followed by the 53-type tool and 5-type tool, while the lowest roughness was achieved with the 9-type tool with the largest reservoir. No clear correlation between the roughness parameters and the welding speed can be observed.

\section{DISCUSSION}

In this paper, the influence of the shoulder configuration of the FSW tool with a square pin was evaluated in relation to the weld tensile, bend and hardness properties, macro-analysis and the surface roughness of the weld faces of the Al5052 plates with a high edge roughness.

The tensile/bending properties and macro-imaging are well correlated. Tunnel and root defects have a considerable influence on the weld properties, causing a decrease in the weld proof strengths, tensile strengths, elongations, corresponding efficiencies, as well as the bending angles to the first crack. Therefore, tunnel-free specimens had the highest mechanical properties and the corresponding weld efficiencies.

Such results can be explained with the nature of the square-pin-tool interaction with the surrounding material at various welding speeds. At a constant rotational speed, a relatively low welding speed causes an increase in the stirring-impulse frequency at a given weld length, leading to a more effective weld filling and defect avoidance. These results support the findings from reference ${ }^{20}$, where a similar, relatively low welding speed was applied for FSW, with a square pin tool, of an Al-alloybased metal-matrix composite reinforced with $\mathrm{TiB}_{2}$ particles. Furthermore, in reference ${ }^{32}$, where the influence of a tunnelling-type defect on the mechanical and metallurgical properties of an Al-Mg alloy was studied, a low welding speed was more effective than high welding speeds, even with the tools having concave shoulders with large reservoirs. Furthermore, a similar finding was reported by Balos and Sidjanin in reference ${ }^{32}$, where a three-sided pin and an unusually large reservoir were used to promote the appearance of a tunnel-like defect. In reference ${ }^{32}$, the highest mechanical properties were obtained with the lowest welding speed $(17 \mathrm{~mm} / \mathrm{min})$ and the highest rotational speed $\left(1230 \mathrm{~min}^{-1}\right)$. The theory that refers to the frequency of impulse stirring at a given weld length is in a marked contrast to the findings of I. Radisavljevic et al. ${ }^{33}$, who reported that the avoidance of a tunnel-like defect depends on the ratio of the rotation to the welding speed, but with the application of a threaded-pin tool.

Two specimens welded at the lowest speed, 01 and 51, also developed a tunnel-like defect. This phenomenon is the result of the tool-shoulder geometry and, therefore, its influence on the material flow. A straight-profile pin without a reservoir (the 0-type tool) provides lower mechanical properties than the 5-type tool, Table 5, indicating that even a relatively small reservoir provides a more convenient material flow. This allows the material to move not only perpendicularly to the tool axis, as forced by the pin, but also parallelly to the tool axis, making the tunnel-like defect smaller (the 5-type tool) or eliminating it at a lower welding speed (the 53- and 9-type tools).

The welding speed also has a marked influence on the hardness of NZ. It can be seen that the increase in the welding speed causes a rise in the hardness of NZ for all the specimen groups. This is the result of the added deformation that comes from the increased welding speed due to the pushing action of the pin while passing through the material. On the other hand, NZs of the specimens welded at a lower welding speed are wider compared to the ones of the specimens welded at a higher welding speed. The hardness values of the TMAZ and HAZ zones vary; however, for the majority of the specimens (welded with the 0-, 5- and 9-type tools), a lower welding speed results in a higher average hardness compared to the medium and high welding speeds. This means that the welding speed of $17 \mathrm{~mm} / \mathrm{min}$ enables lower hardness variations throughout the weld. These results are supported by the macrographs of the welds, where a change in the NZ is observed.

With the increase in the welding speed, the NZ to TMAZ transition line, at the advancing side, becomes closer to a vertical (normal to the specimen surface), while, at the retreating side, the NZ to TMAZ transition line gradually diminishes. This observation is supported by the hardness measurements, which suggest that the hardness drops more gradually in TMAZ at RS than in AS. The reason for such results is difficult to determine, but the major influence may come from the tool-shoulder geometry, which influences the material flow, causing a higher amplitude and lower frequency for the specimens welded with the 5-type tool or a lower amplitude and higher frequency for the specimens welded with the 53-type tool. Furthermore, this also influences the thickness of the NZ under the specimen surface. Namely, a thicker refined NZ under the specimen surface and over the TMAZ and HAZ zones can have a beneficial effect on the mechanical properties. This elongated layer can be regarded as very important for achieving higher proof strength and ultimate tensile strength than those of the base metal.

The results for the weld face roughness strongly depend on the shoulder contact area and the angle of the shoulder contact surface with the reservoir. It can be seen that the 5- and 9-type tool-shoulder contact areas are equal. This implies that a larger angle found for the 9-type-tool outer/external portion of the reservoir has a beneficial influence on the surface-profile finishing, preventing excessive adhesion of the base metal to the tool material. On the other hand, for the 0-type tool, a larger contact area (374 versus $163 \mathrm{~mm}^{2}$ ) proved to have an adverse effect, probably due to the adhesion of the base material. For the 53-type tool, a larger angle of the 
concentric reservoirs has a secondary importance compared to a larger contact area (226 versus $\left.163 \mathrm{~mm}^{2}\right)$ and the existence of the secondary, tertiary and quaternary contacts between the tool shoulder and the base material that have a negative effect on the roughness parameters. According to the results shown in Table 6, there is no firm correlation between the roughness parameters and the welding speed.

Table 6: Roughness parameters obtained with different tools and FSW speeds

Tabela 6: Parametri hrapavosti, dobljeni z različnimi orodji in pri različnih hitrostih FSW

\begin{tabular}{|c|c|c|c|}
\hline & $R_{\mathrm{a}}(\mu \mathrm{m})$ & $R_{\mathrm{y}}(\mu \mathrm{m})$ & $R_{\mathrm{z}}(\mu \mathrm{m})$ \\
\hline 01 & 3.24 & 32.13 & 21.64 \\
\hline 04 & 2.41 & 14.51 & 17.33 \\
\hline 09 & 4.17 & 20.85 & 26.14 \\
\hline 51 & 2.48 & 15.27 & 13.10 \\
\hline 54 & 1.35 & 12.69 & 8.05 \\
\hline 59 & 2.05 & 10.40 & 8.94 \\
\hline 531 & 1.46 & 12.78 & 8.29 \\
\hline 534 & 2.51 & 18.30 & 14.07 \\
\hline 539 & 2.02 & 12.90 & 11.59 \\
\hline 91 & 1.95 & 16.84 & 12.89 \\
\hline 94 & 1.14 & 10.94 & 6.46 \\
\hline 99 & 1.11 & 7.32 & 5.84 \\
\hline
\end{tabular}

\section{CONCLUSIONS}

According to the presented results, some conclusions can be drawn:

- The tool with a square pin and three concave reservoirs, with a reservoir-to-pin volume ratio of 0.5 enables proof and ultimate tensile strengths to surpass those of the base metal. The main reason for such mechanical properties is the characteristic shape of NZ that overlaps with TMAZ and HAZ.

- The welding speed of $17 \mathrm{~mm} / \mathrm{min}$ enables the avoidance of the tunnel-like defect. This way, a full $180^{\circ}$ bending over the weld root can be achieved.

- Low welding speeds are needed for achieving an increase in the stirring-impulse frequency at a given weld length. This enables a more effective weld filling and defect avoidance.

- Weld surface-roughness parameters are considerably lower for the specimens welded with the tools with reservoirs than with the tools without a reservoir.

- A relatively rough edge-surface texture of the basemetal specimens can be successfully overcome with a careful optimization of the tool geometry and welding speed, providing higher proof and ultimate tensile strengths compared to the base metal.

\section{Acknowledgement}

The authors are very grateful to Mr. Ninkovic Mladen from the company Unimet DOO in Novi Sad, Serbia, for his valuable help in determining the roughness parameters of the specimens.

\section{REFERENCES}

${ }^{1}$ W. M. Thomas, E. D. Nicholas, J. C. Needham, M. G. Murch, P. Templesmith, C. J. Dawes, International Patent Application No. PCT/GB92/02203, GB Patent Application No. 9125978.8 (Dec. 1991) and U.S. patent No. 5, 460, 317 (Oct. 1995)

${ }^{2}$ H. Khodaverdizadeh, A. Mahmoudi, A. Heidarzadeh, E. Nazari, Effect of friction stir welding (FSW) parameters on strain hardening behavior of pure copper joints, Materials and Design, 35 (2012), 330-334, doi:10.1016/j.matdes.2011.09.058

${ }^{3}$ G. Ypekoglu, B. G. Kiral, S. Erim, G. Cam, Investigation of the effect of temper condition on the friction-stir weldability of a7075 Al-alloy plates, Mater. Tehnol., 46 (2012) 6, 627-632

${ }^{4}$ L. Fratini, G. Buqa, D. Palmeri, J. Hua, R. Shivpuri, Material flow in FSW of AA7075-T6 butt joints: numerical simulations and experimental verifications, Science and Technology of Welding and Joining, 11 (2006), 412-421, doi:10.1179/174329306X113271

${ }^{5}$ R. S. Mishra, Z. Y. Ma, Friction stir welding and processing, Materials Science and Engineering R, 50 (2005), 1-78, doi:10.1016/ j.mser.2005.07.001

${ }^{6}$ P. L. Threadgill, A. J. Leonard, H. R. Shercliff, P. J. Withers, Friction stir welding of aluminium alloys, International Materials Review, 54 (2009) 2, 49-93, doi:10.1179/174328009X411136

${ }^{7}$ L. Magnusson, L. Kallman, Mechanical Properties of Friction Stir Welds in Thin Sheet of Aluminium 2024, 6013 and 7475, Proc. of the 2nd International Symposium on Friction Stir Welding, Gothenburg, Sweden 2000, 26-28

${ }^{8}$ N. Afrin, D. L. Chen, X. Cao, M. Jahazi, Microstructure and tensile properties of friction stir welded AZ31B magnesium alloy, Materials Science and Engineering A, 472 (2008), 179-186, doi:10.1016/ j.msea.2007.03.018

${ }^{9}$ G. M. Xie, Z. Y. Ma, L. Geng, Effect of microstructural evolution on mechanical properties of friction stir welded ZK60 alloy, Materials Science and Engineering A, 486 (2008), 49-55, doi:10.1016/ j.msea.2007.08.043

${ }^{10}$ S. M. Chowdhury, D. L. Chen, S. D. Bhole, X. Cao, Tensile properties of a friction stir welded magnesium alloy: Effect of pin tool thread orientation and weld pitch, Materials Science and Engineering A, 527 (2010), 6064-6075, doi:10.1016/j.msea.2010.06.012

${ }^{11}$ T. Debroy, H. K. D. H. Bhadeshia, Friction stir welding of dissimilar alloys - a perspective, Science and Technology of Welding \& Joining, 15 (2010) 4, 266-270, doi:10.1179/174329310X1272649 607240

${ }^{12}$ O. Frigaard, A Process Model for FSW of Age Hardening Aluminium Alloys, Ph.D. Thesis, Norwegian University of Science and Technology, 1999

${ }^{13}$ J. Quyang, R. Kovacevic, Material flow and microstructure in the friction stir butt welds of the same and dissimilar aluminum alloys, Journal of Materials Engineering and Performance, 11 (2002) 1, 51-63, doi:10.1007/s11665-002-0008-0

${ }^{14}$ Z. Barlas, U. Ozsarac, Effects of FWS parameters on joint properties of AlMg3 alloy, Welding Journal, 91 (2012), 16-22

${ }^{15}$ R. S. Mishra, M. W. Mahoney, Friction Stir Welding and Processing, ASM International, Materials Park, Ohio, USA 2007

${ }^{16}$ A. Zivkovic, The influence of tool geometry on FSW process, Ph.D. Thesis, University of Belgrade, 2010

${ }^{17}$ R. Rai, A. De, H. K. D. H. Bhadeshia, T. DebRoy, Review: friction stir welding tools, Science and Technology of Welding \& Joining, 16 (2011) 4, 325-342, doi:10.1179/1362171811y.0000000023

${ }^{18}$ Y. N. Zhang, X. Cao, S. Larose, P. Wanjara, Review of tools for friction stir welding and processing, Canadian Metallurgy Quarterly, 51 (2012) 3, 250-261, doi:10.1179/1879139512y.0000000015 
${ }^{19}$ P. Podrzaj, B. Jerman, D. Klobcar, Welding defects at friction stir welding, Metalurgija, 54 (2015), 387-389

${ }^{20}$ W. Yuan, R. S. Mishra, S. Webb, Y. L. Chen, B. Carlson, D. R. Herling, G. J Grant, Effect of tool design and process parameters on properties of Al alloy 6016 friction stir spot welds, Journal of Materials Processing Technology, 211 (2011) 6, 972-977, doi:10.1016/j.jmatprotec.2010.12.014

${ }^{21}$ P. A. Colegrove, H. R. Shercliff, Development of Trivex friction stir welding tool, Part 1 - two-dimensional flow modelling and experimental validation, Science and Technology of Welding and Joining, 9 (2004) 4, 345-351, doi:10.1179/136217104225021670

${ }^{22}$ D. Klobčar, J. Tušek, A. Smolej, S. Simončič, Parametric study of FSSW of aluminium alloy 5754 using a pinless tool, Weld World, 59 (2015), 269-281, doi:10.1007/s40194-014-0208-X

${ }^{23}$ D. A. Burford, B. M. Tweedy, C. A. Widener, Influence of shoulder configuration and geometric features on FSW track properties, $6^{\text {th }}$ International Symposium on Friction Stir Welding, Saint-Sauveur, Montreal, Canada, Paper No. 36, 2006

${ }^{24}$ G. Bussu, P. E. Irving, Fatigue Performance of Friction Stir Welded 2024-T3 Aluminium Joints, 1st International Symposium on Friction Stir Welding, TWI, United Kingdom 1999

${ }^{25}$ M. J. Peel, A. Steuwer, P. J. Withers, T. Dickerson, Q. Shi, H. Shercliff, Dissimilar friction stir welds in AA5083-AA6082, Part I: Process parameter effects on thermal history and weld properties, Metallurgical and Materials Transactions A, 37 (2006) 7, 2183-2193, doi:10.1007/BF02586138
${ }^{26}$ S. J. Vijay, N. Murugan, Influence of tool pin profile on the metallurgical and mechanical properties of friction stir welded Al-10 wt.\% TiB2 metal matrix composite, Materials and Design, 31 (2010) 7 , 3585-3589, doi:10.1016/j.matdes.2010.01.018

${ }^{27}$ S. Brinckmann, A. Strombeck, C. Schilling, J. F. Santos, D. Lohwasser, M. Kocak, Mechanical and Toughness Properties of Robotic-FSW Repair Welds in 6061-T6 Aluminum Alloys, Proceedings of the Second International Conference on Friction Stir Welding, Gothenburg, Sweden, 2000

${ }^{28}$ C. J. Dawes, W. M. Thomas, Development of Improved Tool Designs for Friction Stir Welding of Aluminum, Proceedings of the First International Conference on Friction Stir Welding, Thousand Oaks, CA, 1999

${ }^{29}$ T. Pan, Friction stir spot welding (FSSW) - a literature review, SAE Technical Paper 2007-01-1702, 2007, doi:10.4271/2007-01-1702

${ }^{30}$ P. H. F. Oliveira, S. T. Amancio-Filho, J. F. Dos Santos, E. Hage, Preliminary study on the feasibility of friction spot welding in PMMA, Materials Letters, 64 (2010), 2098-2101, doi:10.1016/ j.matlet.2010.06.050

${ }^{31}$ E. P. Degarmo, J. T. Black, R. A. Kohser, Materials and Processes in Manufacturing, 9th ed., John Wiley and Sons, New York 2003, 60

${ }^{32}$ S. Balos, L. Sidjanin, Effect of tunneling defects on the joint strength efficiency obtained with FSW, Mater. Tehnol., 48 (2014) 4, 491-496

${ }^{33}$ I. Radisavljevic, A. Zivkovic, N. Radovic, Avoidance of tunnel type defects in FSW welded Al 5052-H32 plates, Welding \& Welded Structures, 1 (2012) 1, 5-11 